\title{
Doctoral dissertations in logistics and supply chain management: a review of Nordic contributions from 2009 to 2014
}

\author{
Christopher Rajkumar $^{1} \cdot$ Lone Kavin $^{1} \cdot$ Xue Luo $^{1} \cdot$ Jan Stentoft $^{1}$
}

Received: 2 November 2015/Accepted: 17 February 2016/Published online: 14 March 2016

(C) The Author(s) 2016. This article is published with open access at Springerlink.com

\begin{abstract}
The purpose of this paper is to identify and analyze Nordic doctoral dissertations in logistics and supply chain management (SCM) published from the years 2009-2014. The paper is based on a detailed review of 150 doctoral dissertations. Compared with previous studies, this paper identifies a trend toward: more dissertations based on a collection of articles than monographs; more dissertations focusing on inter-organizational SCM issues; a shift from a focal company perspective to functional aspects and supply chain-related research; and finally, a continued decreased focus on the philosophy of science. A score for measuring the significance of article-based dissertations is also proposed.
\end{abstract}

Keywords Doctoral dissertations - Collection of articles . Monographs - Dissertation score - Logistics and supply chain management

\section{Introduction}

One way to keep track of the progress of logistics and supply chain management (SCM) discipline is to analyze the doctoral dissertations within the research area. By

Jan Stentoft

stentoft@sam.sdu.dk

Christopher Rajkumar

cra@sam.sdu.dk

Lone Kavin

loka@sam.sdu.dk

Xue Luo

$\mathrm{xl@sam.sdu.dk}$

1 Department of Entrepreneurship and Relationship Management, University of Southern Denmark, Kolding, Denmark reviewing such dissertations, it will be possible to gain some interesting information regarding the development and direction of research within the discipline. Specifically, such a review will help us to understand the different approaches in relation to research framework, methodologies, theories applied and the empirical interpretations. Furthermore, the review could not only provide valuable insights into potential research gaps within the discipline, but also pave way for recognizing interesting topics for future research [13, 41]. Besides, given that $\mathrm{PhD}$ students are likely to form the next generation of established researchers, research conducted by them is important to the SCM discipline as it helps keeping the discipline on track with emerging topics as well as stimulate theory generation.

The number of $\mathrm{PhD}$ students in the Nordic countries has increased significantly during the last decades [24, 41]. Based on the rise in the number of dissertations as well as their varying content, it is interesting to investigate the requirements that are part of completing a $\mathrm{PhD}$ dissertation. There has been an escalation in dissertations that are based on collections of articles instead of a monograph [41]. A reason for this might be an increasing pressure to publish at the universities [21], which might be driving PhD students to learn and master the craft of publishing from the very start of their career. No matter what, the culture of many research departments is characterized by a high focus on performance in terms of publications in ranked journals $[2$, $20,22,27]$. Therefore, by choosing an article-based dissertation, $\mathrm{PhD}$ students might have a better opportunity to work together with other $\mathrm{PhD}$ students and senior researchers; in doing so, they also learn how to "play the game."

The first two comprehensive digest of doctoral dissertations completed within the Nordic countries was 
conducted by Gubi et al. [13] and Zachariassen and Arlbjørn [41]. These efforts provide PhD students, other academic staff as well as practitioners with an overview of what has been researched within the logistics and SCM area. These studies have also facilitated the comparison of Nordic dissertations themes to those in the USA (e.g., compiled by Stock [31] and Nakhata et al. [25]). Prior research has demonstrated that much confusion exists concerning SCM definitions and its overlap with logistics [32]. This paper extends the work of Zachariassen and Arlbjørn [41] that applies what Halldórsson et al. [14] call a relabeling approach between the terms of logistics and SCM. The purpose of this paper is to document the progress of doctoral work in logistics and SCM within the Nordic countries between 2009 and 2014. In all, 120 relevant dissertations were identified; however, we were unable to retrieve eight dissertations either in physical form or electronically; therefore, only 112 dissertations were reviewed. With a point of departure within the dimensions and classified categories of these two above-mentioned reviews, this paper provides two analyses:

1. An analysis of identified Nordic dissertations from the year 2009-2014; and

2. A longitudinal analysis that compares the above analysis with the result from Gubi et al. [13] and Zachariassen and Arlbjørn [41].

Accordingly, the analyses within this paper will not only reveal several important insights, but also identify new, potential research areas within the logistics and SCM discipline. Based on these insights, it will be possible to coordinate future research efforts and avoid any unnecessary replication or duplication of previous work.

The rest of the paper is organized as follows: Sect. 2 provides a brief literature review of earlier contributions dealing with doctoral dissertation reviews. Section 3 discusses the methodology used in this study; it also outlines the limitations concerning the chosen methodology. Subsequently, Sect. 4 discusses the results obtained from analyzing the Nordic dissertations. Finally, Sect. 5 concludes with the overall purpose of the paper and some directions for future research activities.

\section{Extant literature on doctoral dissertations in logistics and supply chain management}

Several authors have analyzed and classified doctoral dissertations in logistics and SCM, both within the Nordic countries as well as the USA. In this section, nine prior studies-seven American studies and two Nordic studiesare briefly mentioned so as to identify the trends in topical coverage through the years and to see whether there are any similarities between the topics chosen by $\mathrm{PhD}$ students across the Atlantic.

The first study of compendiums of $\mathrm{PhD}$ research in logistics conducted by Stock back in 1987 [28] examined 684 dissertations from the period 1970-1986 [29]. Subsequent reviews were conducted in (1) 1993 covering 422 American dissertations that were completed in the period of 1987-1991 [34] and (2) 2001 with an analysis of $317 \mathrm{PhD}$ dissertations completed in the period of 1992-1998 [31]. In 2006, Stock completed his fourth review of PhD dissertations together with Broadus [33]. This study showed a distinct increasing trend in the number of dissertations within SCM- and/or logistic-related areas in the period from 1999 to 2004 when compared to the period covered by the 2001 study. But surprisingly, the count between 1999 and 2004 fell short of the overall levels of 1987-1991. A more interesting finding of the 2006 study was that the dissertations were more multifaceted due to the fact that they closely mirrored the cross-functional and boundary spanning nature of logistics; at the same time, their multifaceted nature made the classification task more difficult.

Another American study was conducted by Das and Handfield [8] wherein the authors investigated $117 \mathrm{PhD}$ dissertations from the period 1987-1995 in order to evaluate the intellectual health of the purchasing discipline. The study was an extension of a previous research on purchasing dissertations conducted by Williams [39] to identify the key focus areas of research in the prior decade. In this study, Williams concluded that the key focus areas covered were supplier selection and development, information systems, organizational and measurement issues, negotiation and purchasing ethics.

The most recent review covering US dissertations was conducted by Nakhata et al. [25]. In this study, the authors reviewed 609 doctoral dissertations completed between 2005 and 2009. The number of identified dissertations in this study is significantly larger than the four reviews conducted by Stock and colleagues and clearly reflects a significant increase in colleges/universities graduating doctoral students within logistics- and supply chain-related areas. Nakhata et al. [25] also point out that a forthcoming retirement of academic "baby boomers" during the period 2005-2020 may explain the increase in the $\mathrm{PhD}$ production. The most prominent research methodologies employed by doctoral students in the study of Nakhata et al. [25] are modeling, simulation and empirical quantitative methods.

Two earlier studies of Nordic doctoral dissertations within logistics and SCM have been disseminated in academic journals. The first was developed by Gubi et al. [13], who reviewed 71 Nordic dissertations published between 1990 and 2001. Most of the dissertations were published as monographs with manufactures and carriers as the primary 
entity of analysis. The most recent Nordic contribution is by Zachariassen and Arlbjørn [41] wherein the authors analyze the development in Nordic doctoral research in logistics and SCM from the years 2002-2008. As opposed to Gubi et al. [13], Zachariassen and Arlbjørn [41] found more dissertations based on a collection of articles, which was reflective of a response to increase publication pressure. In contrast to the Gubi et al.'s [13] study, the primarily entity of analysis of most dissertations was the manufacturing companies. While prior reviews showed a focal company perspective, the review of Zachariassen and Arlbjørn [41] documented a shift toward an inter-organizational perspective covering dyadic and supply chain units of analysis. Additionally, according to Zachariassen and Arlbjørn [41], there has also been a decreased focus on the philosophy of science, since most dissertations were being published as collections of articles.

\section{Method}

The method applied for identifying, collecting and reviewing the doctoral dissertations in this paper follows a three-step process. These steps are explained in the following subsections.

\subsection{Identifying and collecting Nordic doctoral dissertations}

The first step consisted of sending e-mails to contact persons at different research institutions within the Nordic countries (i.e., Denmark, Finland, Iceland, Norway and Sweden) as outlined in [41]. Based on this e-mail contact, the list was further modified (e.g., adding University of Vaasa in Finland and Linnaeus University and Örebro University School of Business in Sweden). The final list included 39 research institutions which are presented in "Appendix 1." A contact person at each of the 39 research institution was identified and was contacted by e-mail. The e-mail provided a clear statement of the research project and requested the list of completed doctoral dissertations within logistics and SCM within the analysis period. This process provided an initial list of 120 dissertations. Majority of these dissertations were accessible in electronic form (we either received them by e-mail or downloaded them from the corresponding institution's Web site). The rest of the dissertations were available in hard copy form.

\subsection{Validating the initial list of doctoral dissertations}

The second step was concerned with the validation of the identified dissertations by senior researchers from each of the Nordic countries. This step was completed by e-mailing the initial list to these senior researchers and by attending the 27th annual NOFOMA conference in June 2015 at Molde University College. This process resulted in the inclusion of an additional 41 dissertations, thereby increasing the total count to 161 .

\subsection{Reviewing the received dissertations}

In the third step, a detailed review of the 161 dissertations took place. During this process, three dissertations were excluded since they were judged as not being within the scope of the present analysis. Out of this net list of 158, it was possible to conduct reviews of 150 dissertations. As mentioned earlier, we were unable to retrieve eight dissertations as well as there was no response from the authors when we e-mailed them requesting for the copy of their dissertation. A complete list of the dissertations is included in "Appendix 2." The detailed review took place against a review framework as described in [13, 41]. Our analysis covered additional review elements as the dissertations were mostly based on a collection of articles. These elements were: (1) number of articles, (2) type of article (journal publication, book chapter, conference paper, working paper or unpublished paper), (3) year of publication, (4) ranking of the journal, (5) number of authors on each article and (6) the doctoral candidate's author number for the specific article.

\subsection{Limitations}

This dissertation review has some limitations that are worthwhile to mention. First, even though the gross list of dissertations was reviewed and validated by senior researchers within the Nordic countries, there is a possibility that some dissertations were not identified. Second, reviewer subjectivity could not be completely eliminated in the review of the 150 dissertations. However, in order to minimize subjectivity, an aligned interpretation of the review elements and their outcome was obtained by a common review of three different types of dissertations (one monograph and two article-based dissertations). Third, the list of dissertations that was composed and reviewed stems from the NOFOMA research community. Obviously, other Nordic researchers may produce doctoral dissertations that deal with topics under the scope of this review, but is outside the NOFOMA radar (e.g., researchers belonging to European Decision Sciences Institute (EDSI), European Logistics Association (ELA), European Operations Management (EurOMA), International Purchasing and Supply Education and Research Association (IPSERA) or Logistics Research Network (LRN) or Rencontres Internationales de Recherche en Logistique (RIRL) 
(International Research Conference on Logistics and Supply Chain Management). This study can make observations only based on the dissertations reviewed under the NOFOMA umbrella. Fourth, since the contact persons were not provided with a definition of logistics and SCM, they might have excluded some dissertation that could have fallen within the scope of this analysis. Moreover, the senior researchers whom we e-mailed for dissertations might not be from the department of logistics and SCM. Therefore, including definitions for logistics and SCM will have no impact.

\section{Analysis}

This section is concerned with specific analyses of the 150 reviewed doctoral dissertations. For comparative purposes, the data from the present review are portrayed and analyzed with the categories that are similar to those used by Gubi et al. [13] and Zachariassen and Arlbjørn [41]. The results are displayed in tables and are followed with appropriate comments and interpretations.

\subsection{Number and type of dissertations finalized in the period 2009-2014}

Table 1 contains the $\mathrm{PhD}$ dissertations divided by country, year of publication and type of dissertation (monograph vs. a collection of articles). Compared with the earlier studies, these new figures show some interesting developments. First, the number of finalized dissertations in the period 2009-2014 is 158, which represents an average of 26 dissertations per year. Compared with averages numbers of 10 (from the period 2002-2008) and 6.25 (from the period 1990-2001), this shows that there has been a strong increase in $\mathrm{PhD}$ production in this research area. A similar pattern is identified by Nakhata et al. [25] in their study of doctoral dissertations published by Dissertation Abstracts International in the period of 2005 and 2009. They explain that one reason for such an increase might be an increased level of retiring academicians toward 2020 which creates a stronger market for Assistant Professors. Another explanation could be that there is a drive from the governments to boost the number of annual $\mathrm{PhD}$ production in order to support national social, economic and environmental well-being as well as to address major global challenges [12]. The majority of the Nordic logistics and SCM PhDs come from the Finnish, Norwegian and Swedish research environments. In Denmark, the production is stable with 17 dissertations in the period of 2009-2014. Iceland has reported their first $\mathrm{PhD}$ in this period of analysis. Twenty-five Nordic research institutions have produced within logistics and SCM in the period 2009-2014 (see "Appendix 2").
Another interesting finding in the current review is the increase in the share of dissertations that are based on a collection of articles. As given in Table 1,92 out of the 150 dissertations $(61 \%)$ are based on a collection of articles. Thus, there is a much higher focus on the craft to write academic articles when compared to the share of articlebased dissertations in previous periods $(29 \%$ in the period 2002-2008 and $21 \%$ in the period 1990-2001). This trend supports the predictions previously made by Zachariassen and Arlbjørn [41]. One plausible explanation for this development might be an increased amount of public and private resource allocation to research environments based on publications in internationally recognized peer-reviewed journals as well as measures such as impact indicators and H-index (see, e.g., [27]).

\subsection{Primary entity of analysis}

In Table 2, all 150 dissertations are classified according to their entity of analysis; the classifications are also compared to previous results reported in $[13,14]$. The study of the primary entity of analysis in the dissertations shows strong differences. First, the category others has increased to about one-third of the dissertations in the last reported period. This group consists of a variety of dissertations without a specific supply chain actors' perspective-such as fresh fish supply chains [26] and healthcare logistics [17]. Second, in absolute numbers, the manufacturer as the primary entity of analysis has increased when compared to the previous studies; but, if we measure the number as a percentage of the reviewed dissertations, there is a fall from $57 \%$ in the dissertations from 2002 to 2008 to $33 \%$ in the recent study.

Thus, it shows the more classical actors such as wholesalers, retailers and inventory hotels have obtained lesser research focus. Additionally, a remarkably low number of dissertations have focused on retail SCM within the Nordic countries. This is intriguing given the fact that the retail sector is well known for supply chain innovations such as quick response systems, efficient consumer response, distribution centers, reverse logistics, as well as collaborative planning, forecasting and replenishment [10].

\subsection{Level of analysis arranged according to year of publication}

Table 3 shows the analysis of the dissertations level of analysis arranged by the year of publication.

An interesting development evidenced in the above table is an increased focus on functional themes within dissertations (in the present analysis, this is about $26 \%$ of the dissertations compared with 11 and $10 \%$ in previous analyses). This development is primarily driven by Finnish 
Table 1 Number and type of PhD dissertations finalized in the period 2009-2014

\begin{tabular}{|c|c|c|c|c|c|c|c|c|c|}
\hline & 2009 & 2010 & 2011 & 2012 & 2013 & 2014 & Total (2009-2014) & Total (2002-2008) & Total (1990-2001) \\
\hline \multicolumn{10}{|c|}{ All identified dissertations } \\
\hline Danish & 2 & 1 & 4 & 3 & 5 & 2 & 17 & 11 & 15 \\
\hline Finnish & 10 & 9 & 7 & 8 & 6 & 8 & 48 & 22 & 20 \\
\hline Icelandic & - & 1 & - & - & - & - & 1 & - & - \\
\hline Norwegian & 6 & 5 & - & 5 & 6 & 5 & 27 & 17 & 12 \\
\hline Swedish & 9 & 10 & 12 & 13 & 9 & 12 & 65 & 20 & 28 \\
\hline Total & 27 & 26 & 23 & 29 & 26 & 27 & 158 & 70 & 75 \\
\hline \multicolumn{10}{|l|}{ Reviewed dissertations } \\
\hline \multicolumn{10}{|l|}{ Danish reviewed } \\
\hline Monograph & 2 & - & 1 & 1 & 1 & 0 & 5 & 9 & 14 \\
\hline Collection of articles & - & 1 & 3 & 2 & 4 & 2 & 12 & 2 & 1 \\
\hline Total Danish & 2 & 1 & 4 & 3 & 5 & 2 & 17 & 11 & 15 \\
\hline \multicolumn{10}{|l|}{ Finnish reviewed } \\
\hline Monograph & 2 & 2 & 5 & 4 & 2 & 3 & 18 & 13 & 14 \\
\hline Collection of articles & 8 & 6 & 2 & 3 & 4 & 4 & 27 & 9 & 3 \\
\hline Total Finnish & 10 & 8 & 7 & 7 & 6 & 7 & 45 & 22 & 17 \\
\hline \multicolumn{10}{|l|}{ Icelandic reviewed } \\
\hline Monograph & - & 1 & - & - & - & - & 1 & - & - \\
\hline Collection of articles & - & - & - & - & - & - & 0 & - & - \\
\hline Total Icelandic & 0 & 1 & 0 & 0 & 0 & 0 & 1 & 0 & 0 \\
\hline \multicolumn{10}{|l|}{ Norwegian reviewed } \\
\hline Monograph & 5 & 1 & - & 1 & 2 & 2 & 11 & 9 & 9 \\
\hline Collection of articles & 1 & 4 & - & 4 & 4 & 3 & 16 & 8 & 2 \\
\hline Total Norwegian & 6 & 5 & 0 & 5 & 6 & 5 & 27 & 17 & 11 \\
\hline \multicolumn{10}{|l|}{ Swedish reviewed } \\
\hline Monograph & 2 & 6 & 4 & 5 & 1 & 5 & 23 & 13 & 19 \\
\hline Collection of articles & 6 & 2 & 7 & 8 & 7 & 7 & 37 & 7 & 9 \\
\hline Total Swedish & 8 & 8 & 11 & 13 & 8 & 12 & 60 & 20 & 28 \\
\hline \multicolumn{10}{|l|}{ Reviewed on total } \\
\hline Monograph & 11 & 10 & 10 & 11 & 6 & 10 & 58 & 44 & 56 \\
\hline Collection of articles & 15 & 13 & 12 & 17 & 19 & 16 & 92 & 26 & 15 \\
\hline Total & 26 & 23 & 22 & 28 & 25 & 26 & 150 & 70 & 71 \\
\hline
\end{tabular}

Comparable data are included from the period 1990-2001 (Gubi et al. [13]) and 2002-2008 (Zachariassen and Arlbjørn [41])

dissertations and can indicate an emphasis on building stronger knowledge bases in certain sub-disciplines along the supply chain. Examples of such dissertations are [18, 19]. Another interesting development is the reduced focus on firm-level analysis and a subsequent increased focus on the supply chain or the network as the level of analysis, with the network level experiencing the highest increase. This increase is strongly evident within Swedish dissertations.

\subsection{Research design, time frame and philosophy of science}

Table 4 shows the classification of the dissertations according to research design, time frame and philosophy of science. The recent analysis reveals a decrease in share of dissertations that are purely theoretical in nature. Also, the share of dissertations founded on purely qualitative methods has also decreased compared with dissertations published in the period 2002-2008. The drop in share of these two categories has attributed to increases in shares of dissertations based on quantitative methods and on triangulations of qualitative and quantitative research methods. The increase in quantitative research methods can be explained by the increased pressure to publish, thereby favoring quantitative methods over time-consuming qualitative studies (see, e.g., [21]). While quantitative data collection can be automated, it is not possible for qualitative data collection. Qualitative data collection is, in general, more time-consuming and expensive when compared 
Table 2 Primary entity of analysis

\begin{tabular}{|c|c|c|c|c|c|c|c|c|c|c|c|c|c|c|c|c|c|c|}
\hline & \multicolumn{3}{|c|}{ Danish } & \multicolumn{3}{|c|}{ Finnish } & \multicolumn{3}{|c|}{ Icelandic } & \multicolumn{3}{|c|}{ Norwegian } & \multicolumn{3}{|c|}{ Swedish } & \multicolumn{3}{|c|}{ Total } \\
\hline & A & B & $\mathrm{C}$ & A & B & $\mathrm{C}$ & A & B & $\mathrm{C}$ & A & B & $\mathrm{C}$ & A & B & $\mathrm{C}$ & A & B & $\mathrm{C}$ \\
\hline Manufacture & 9 & 9 & 2 & 11 & 11 & 20 & - & - & - & 6 & 9 & 8 & 10 & 11 & 20 & 36 & 40 & 50 \\
\hline Carrier & 5 & 1 & 2 & 3 & 4 & 5 & - & - & - & 3 & 1 & 14 & 10 & 3 & 15 & 21 & 9 & 36 \\
\hline Wholesaler & - & - & - & - & 2 & - & - & - & - & - & 1 & 1 & - & - & 2 & 0 & 3 & 3 \\
\hline Retailer & - & - & - & - & 2 & 3 & - & - & - & - & 1 & 1 & - & 1 & 4 & 0 & 4 & 8 \\
\hline Inventory hotel & - & - & - & - & - & 1 & - & - & - & - & - & 1 & 1 & - & 3 & 1 & 0 & 5 \\
\hline Others & 1 & 1 & 13 & 3 & 3 & 16 & - & - & 1 & 2 & 5 & 2 & 7 & 5 & 16 & 13 & 14 & 48 \\
\hline Total & 15 & 11 & 17 & 17 & 22 & 45 & 0 & 0 & 1 & 11 & 17 & 27 & 28 & 20 & 60 & 71 & 70 & 150 \\
\hline
\end{tabular}

$\mathrm{A}=$ time period 1999-2001 covered in Gubi et al. [13]

B = time period 2002-2008 covered in Zachariassen and Arlbjørn [41]

$\mathrm{C}=2009-2014$ covered in this paper

Table 3 Level of analysis arranged according to year of publication

\begin{tabular}{|c|c|c|c|c|c|c|c|c|c|}
\hline & 2009 & 2010 & 2011 & 2012 & 2013 & 2014 & Total (2009-2014) & Total (2002-2008) & Total (1990-2001) \\
\hline \multicolumn{10}{|l|}{ Total } \\
\hline Function & 6 & 4 & 4 & 7 & 11 & 7 & 39 & 8 & 7 \\
\hline Firm & 1 & 4 & 1 & 0 & 4 & 5 & 15 & 19 & 33 \\
\hline Dyad & 3 & 3 & 4 & 3 & 1 & 2 & 16 & 16 & 8 \\
\hline Supply chain & 7 & 4 & 4 & 9 & 5 & 8 & 37 & 15 & 8 \\
\hline Network & 5 & 7 & 7 & 8 & 5 & 4 & 36 & 8 & 5 \\
\hline Others & 3 & 1 & 2 & 1 & 0 & 0 & 7 & 4 & 10 \\
\hline Total & 25 & 23 & 22 & 28 & 26 & 25 & 150 & 70 & 71 \\
\hline
\end{tabular}

Table 4 Research design, time frame and philosophy of science

\begin{tabular}{|c|c|c|c|c|c|c|c|}
\hline Danish & Finnish & Icelandic & Norwegian & Swedish & $\begin{array}{l}\text { Total } \\
(2009-2014)\end{array}$ & $\begin{array}{l}\text { Total } \\
(2002-2008)\end{array}$ & $\begin{array}{l}\text { Total } \\
(1990-2001)\end{array}$ \\
\hline
\end{tabular}

Research design

Theoretical (desk resear

Empirical quantitative

Empirical qualitative

Empirical triangulation

Research design total

Time frame

Snapshot

Longitudinal

Not specified

Time frame total

Containing philosophy

Yes
No
Total

$\begin{array}{lrr}6 & 2 & - \\ 4 & 9 & - \\ 4 & 17 & 1 \\ 3 & 17 & - \\ 17 & 45 & 1\end{array}$

$\begin{array}{lll}- & - & \\ - & 11 & \\ 1 & 10 & 27 \\ - & 6 & 25 \\ 1 & 27 & 59\end{array}$

7
1
27
25
59

$\begin{array}{rrr}15 & 14 & 21 \\ 25 & 9 & 6 \\ 59 & 31 & 27 \\ 51 & 16 & 17 \\ 150 & 70 & 71\end{array}$

$\begin{array}{lrll}8 & 30 & 1 & 21 \\ 1 & 8 & - & 2 \\ 2 & 5 & - & 4 \\ 11 & 43 & 1 & 27\end{array}$

$\begin{array}{rrrr}16 & 76 & 39 & 41 \\ 22 & 33 & 11 & 6 \\ 15 & 26 & 6 & 3 \\ 53 & 135 & 56 & 50\end{array}$

$\begin{array}{llll}9 & 13 & - & 7 \\ 8 & 32 & 1 & 21 \\ 17 & 45 & 1 & 28\end{array}$

$\begin{array}{lr}11 & 40 \\ 47 & 110 \\ 58 & 150\end{array}$

$\begin{array}{ll}20 & 39 \\ 50 & 32 \\ 70 & 71\end{array}$

to quantitative research studies. Thus, it might be more cost-effective to slice one questionnaire survey into a number of articles than doing the same number of articles based on qualitative methodologies. This trend will undoubtedly improve numerical performance metrics. At the same time, this trend need not necessarily deliver new knowledge that could move the discipline significantly forward. Particularly, quantitative surveys are exposed to 
the phenomenon of "salami-slicing" where the data from a particular project are disseminated in a number of articles that in fact are "sliced" so thinly that there might be overlap of the papers (e.g., text recycling in literature review sections, key findings and discussions $([9,16])$. We refer to the Committee on Publication Ethics (COPE) [7] for a discussion on different forms of text recycling.

Table 4 also shows an increased share of dissertations that apply a longitudinal perspective. Additionally, the share of snapshot time frames has decreased and the share of the category time frame not specified has increased. Examples of dissertations without any specific time frame are by (1) Mortensen [23], who investigate the concept of attraction and explain its role in initiation and development of buyer-seller relations, and (2) Tynjälä [35], who conceptually examines the methods and tools for supply chain decision making during new product development. A final remarkable finding from Table 4 is the continued decline of dissertations containing philosophy of science issues. The present analysis identifies $73 \%$ of the dissertations not including such philosophical considerations in comparison with 71 and $45 \%$ in the two previous periods of analysis. Twentynine percent of dissertations that are monographs do contain philosophy of science considerations, whereas $25 \%$ have this content among the article-based dissertations. Zachariassen and Arlbjørn [41] provided four possible reasons for this decline: (1) There are no mandatory requirements for $\mathrm{PhD}$ students to attend philosophy of science courses, (2) article-based dissertations do not rely on philosophy of science argumentations to the same degree as the monographs that typically require more in-depth interaction of this issues and method considerations, (3) there is a lower prioritization of philosophy of science due to higher pressure from external funded projects that do not demand this theme, and (4) logistics and SCM are closely connected with industry that could lead to a perception that philosophy of science is less relevant. To this list, we add four more potential reasons. First, there are no requirements mentioned in Nordic countries' ministerial orders granting degrees of $\mathrm{PhD}$ about unfolding philosophical of science perspectives. Second, few, if any, journals within logistics and SCM demand such discussions. Third, philosophy of science has disappeared from $\mathrm{PhD}$ candidates' syllabi. Finally, only a few $\mathrm{PhD}$ advisors have the knowledge to join in such discussions with their PhD students; therefore, they do not send signals for offering such courses. Overall, this development is inexpedient if the discipline really has to move toward theory development $[6,30]$.

\subsection{Dissertations distributed according to topic groups and country of origin}

Table 5 displays the dissertations according to topic groups based on a title analysis of the 158 identified dissertations. For comparison reasons, the topic groups identified in previous studies were used [13, 41] and further supplemented with two new groups risk management and humanitarian logistics. The table shows a continued decline in the share of dissertations related to system design/ structure/effectiveness, organizational development/competencies and material handling. In contrast, topics related to system integration/integration enablers and

Table 5 Division of dissertations according to topic groups and country of origin

\begin{tabular}{|c|c|c|c|c|c|c|c|c|c|c|c|c|c|c|c|c|c|c|}
\hline & \multicolumn{3}{|c|}{ Danish } & \multicolumn{3}{|c|}{ Finnish } & \multicolumn{3}{|c|}{ Icelandic } & \multicolumn{3}{|c|}{ Norwegian } & \multicolumn{3}{|c|}{ Swedish } & \multicolumn{3}{|c|}{ Total } \\
\hline & A & $\mathrm{B}$ & $\mathrm{C}$ & A & $\mathrm{B}$ & $\mathrm{C}$ & A & $\mathrm{B}$ & $\mathrm{C}$ & A & B & $\mathrm{C}$ & A & $\mathrm{B}$ & $\mathrm{C}$ & A & $\mathrm{B}$ & $\mathrm{C}$ \\
\hline System design/structure/effectiveness & 5 & 4 & 1 & 10 & 6 & 7 & - & - & 1 & 5 & - & 6 & 5 & 2 & 7 & 25 & 12 & 22 \\
\hline Distribution/route planning & 1 & - & 2 & 3 & - & 2 & - & - & - & 2 & 7 & 6 & 3 & 1 & 2 & 9 & 8 & 12 \\
\hline Organizational development/competencies & 3 & 5 & 1 & 1 & 1 & 10 & - & - & - & - & 2 & 2 & 3 & 2 & 7 & 7 & 10 & 20 \\
\hline System integration/integration enablers & 1 & - & 2 & 1 & 3 & 4 & - & - & - & 1 & 2 & 3 & 5 & 1 & 7 & 8 & 6 & 16 \\
\hline Environmental issues/CSR & - & 1 & 2 & - & 1 & 1 & - & - & - & - & - & 1 & 2 & 1 & 3 & 2 & 3 & 7 \\
\hline Inter-organizational collaboration/third-party logistics & 3 & 1 & 1 & 3 & 3 & 12 & - & - & - & 2 & 2 & - & 3 & 4 & 8 & 11 & 10 & 21 \\
\hline Material handling/material planning & - & - & 5 & - & 3 & - & - & - & - & - & 3 & 3 & 3 & 8 & 6 & 3 & 14 & 14 \\
\hline Transport/transport systems & 2 & - & 1 & 2 & 4 & 5 & - & - & - & 2 & - & 5 & 4 & 1 & 16 & 10 & 5 & 27 \\
\hline Risk management & - & - & - & - & - & 2 & - & - & - & - & - & 1 & - & - & 6 & 0 & - & 9 \\
\hline Humanitarian logistics & - & - & - & - & - & 2 & - & - & - & - & - & - & - & - & 1 & 0 & - & 3 \\
\hline Others & - & - & 2 & - & 1 & 3 & - & - & - & - & 1 & - & - & - & 2 & 0 & 2 & 7 \\
\hline Total & 15 & 11 & 17 & 20 & 22 & 48 & - & - & 1 & 12 & 17 & 27 & 28 & 20 & 65 & 75 & 70 & 158 \\
\hline
\end{tabular}

$\mathrm{A}=$ Time period of 1999-2001 covered in Gubi et al. [13]

$\mathrm{B}=$ Time period of 2002-2008 covered in Zachariassen and Arlbjørn [41]

$\mathrm{C}=$ Time period of 2009-2014 covered in this paper 
transport/transport systems have obtained increased awareness. The increase in these topics is primarily based on Swedish and Norwegian dissertations.

Additionally, while the study by [41] found that topics related to humanitarian logistics and risk management were absent, the present review of dissertations has remedied this with dissertations on this topic from Finland and Sweden.

\subsection{Article-based dissertations}

The study reported in this paper reveals an increased amount of article-based dissertations. This development confirms the expectations raised by Zachariassen and Arlbjørn [41]. However, an article-based dissertation can be composed in different ways-e.g., with respect to requirements regarding the type of articles, number of articles, co-author permission and the author order position among the co-authors in an article. The ministerial orders granting the degree of PhDs in the different countries do not provide any guidance and requirements concerning the format of a PhD. This opens up for various interpretations of the required workload to earn the $\mathrm{PhD}$ degree. Therefore, the increase in more article-based dissertations requires that we study how the practice of these types of dissertations is unfolded in the Nordic countries. This section takes a closer look at the 92 article-based dissertations and develops a measure to differentiate the various types of dissertations. The subsequent subsection proposes a measure for article-based dissertation; this measure is subsequently used in analyzing the identified Nordic article-based dissertations.

\subsubsection{Measure for dissertation score}

In order to develop a measure for an average article-based dissertation, we first need to recognize the fact that a specific article that is part of the dissertation can take different forms. Hence, the first element in this proposal for a dissertation measure is to differentiate between the different types of contributions that are part of the articlebased dissertation and then to allocate different scores for the different types. The present analysis distinguishes between five different types of articles with specific scores as follows:

1. Peer-reviewed journal articles, score: 1

2. Peer-reviewed articles in form of book chapters (e.g., in an anthology), score: 0.8

3. Peer-reviewed conference articles, score: 0.8

4. Working papers, score: 0.5

5. Non-published papers, score: 0.5

The differences in scores are used to reflect different perceptions of workload as well as quality requirements. Thus, a peer-reviewed journal article obtains the highest score of 1 point followed by book chapters and conferences papers with scores of 0.8 , and working papers and nonpublished manuscripts of 0.5 points.

The next step in developing a dissertation score is to propose a measure that takes into account the number of authors as well as the order of the authors. Thus, a sole authored paper by a PhD candidate counts more than a coauthored paper. And, in the present measure, a first-order author position counts more than a lower author position. Table 6 proposes scores for authorship indicators
Table 6 Authorship factor calculation

\begin{tabular}{|c|c|c|c|c|}
\hline \multicolumn{2}{|c|}{ Number of authors (NoA) } & \multicolumn{2}{|c|}{ Author order position (AOP) } & \multirow{2}{*}{$\begin{array}{l}\text { Authorship factor } \\
\text { NoA * AOP }\end{array}$} \\
\hline NoA & Score & AOP & Score & \\
\hline 1 & 1 & 1 & 1 & 1 \\
\hline 2 & 0.9 & 1 & 1 & 0.9 \\
\hline 2 & 0.9 & 2 & 0.9 & 0.81 \\
\hline 3 & 0.8 & 1 & 1 & 0.8 \\
\hline 3 & 0.8 & 2 & 0.9 & 0.72 \\
\hline 3 & 0.8 & 3 & 0.8 & 0.64 \\
\hline 4 & 0.7 & 1 & 1 & 0.7 \\
\hline 4 & 0.7 & 2 & 0.9 & 0.63 \\
\hline 4 & 0.7 & 3 & 0.8 & 0.56 \\
\hline 4 & 0.7 & 4 & 0.7 & 0.49 \\
\hline 5 & 0.6 & 1 & 1 & 0.6 \\
\hline 5 & 0.6 & 2 & 0.9 & 0.54 \\
\hline 5 & 0.6 & 3 & 0.8 & 0.48 \\
\hline 5 & 0.6 & 4 & 0.7 & 0.42 \\
\hline 5 & 0.6 & 5 & 0.6 & 0.36 \\
\hline
\end{tabular}


evaluating each of the articles that take into consideration various numbers of authors and author order positions.

Based on the above proposals of different types of articles and measures for different authorship indicators, we can now develop an overall dissertation score based on Formula 1:

Formula 1: overall dissertation score

$S=\sum_{i=1}^{n} T_{i} *$ Authorship factor ${ }_{i}$

where $S=$ overall dissertation score, $T=$ type of article and authorship factor $=$ number of authors $(\mathrm{NoA}) *$ author order position (AOP).

The overall dissertation score is composed of multiplying the scores of the individual articles by the authorship factor. The basic idea is that the highest score per article of 1 point is reduced based on the lower the level of the perceived status of various channels (e.g., journal rankings; journal articles versus book chapters; conference articles versus journal articles/book chapters) and the number of co-authors as well as the author order the $\mathrm{PhD}$ student has for the given article. A conference paper that is included in an article-based dissertation, which have been through a double-blind review process (e.g., at a NOFOMA, LRN or a EurOMA conference), is valued 0.8 compared with an article that is published in a peer-reviewed journal. Thus, a conference article is considered as less mature when compared to an article that has been through perhaps several revisions in a journal before acceptance. However, we should avoid with the generalization of the different channels. The Danish Bibliometric Research Indicator, for example, value accepted conference articles as much as some journal papers, if they are accepted to be presented at some conferences (e.g., EURAM and AOM) [36]. Also, contributions to books are valued differently according to which publisher the work is published with [37].

The dissertation score is a measure for the $\mathrm{PhD}$ dissertation at hand-and thus, the status of it when it was judged and passed. Several article-based dissertations contain nonpublished papers, working papers and conference articles that find its way to peer-reviewed journals after the degree of $\mathrm{PhD}$ has been awarded and further workload is invested in those articles. Other articles of this nature never end in publications for various reasons. Thus, the status of the papers after the $\mathrm{PhD}$ evaluation is not included in the dissertation score presented in this article.

An article-based dissertation is evaluated not only on the enclosed articles, but also on the text (the frame) that bind the articles together. Also, herein there seems to be different practices-e.g., the scope and depths on positioning the thesis against extant research; the level and scope of methodological and philosophy of science discussions (see, e.g., [3]); independent literature reviews as well as discussions on the "red line" between the included articles.

The overall purpose with the dissertation score is to propose a measure to be used for discussing the scope and content-type of a $\mathrm{PhD}$ dissertation. What is enough? And how much of a dissertation can be co-authored with others? Is one dissertation better than another because it includes articles that are published? It is our experience that there are differences in what is needed in an article-based dissertation both within a department at a research institution and between research institutions. The present dissertation score can help in discussing what is needed and also in developing department guidelines.

The proposed overall dissertation score formula is not without limitations. First, the division of types of articles and their scores is subjective. The peer-reviewed journal category, for example, can be further divided into different scores by following specific journal ranking lists. Second, the scores for various numbers of authors and their author order position in the proposed authorship factor calculation are also subjective and can be altered. The order of authors of a paper does not necessarily display the true workload of different authors. The order of authors can be organized using different principles such as a simple alphabetical listing, organized after seniority (experience); listing the person first who got the idea to the article as the first author; or listing PhD students first because they need the credit more than their senior co-authors. Third, the dissertation score does not include a time perspective (i.e., the length of the PhD program) - a higher score can be obtained over a 5-year period when compared to a 3-year period. Fourth, the dissertation score does not take into consideration the extent of thesis frame (the text accompanying the articles such as scoping, positioning, methods, philosophy of science, contribution and implications). Fifth, the score of author order position decreases based on the position; this may not reflect the actual work load. In summary, as with any measures in general, this overall dissertation score also has its own shortcomings and these are important to be considered to ensure the practical use of the score. However, in spite of the sometime magical status of numbers-we should remember that "numbers are just number" and that they can be used to jump start discussions on how to compose an article-based dissertation.

\subsubsection{Dissertation scores}

This section provides an analysis of the 92 article-based dissertations using the dissertation score developed in the above subsection. This number is divided among 12 
Table 7 Contents of articlebased dissertations

\begin{tabular}{|c|c|c|c|c|c|c|c|c|c|c|c|}
\hline & & Art. 1 & Art. 2 & Art. 3 & Art. 4 & Art. 5 & Art. 6 & Art. 7 & Art. 8 & Total & Avg DS \\
\hline \multirow[t]{3}{*}{3 Articles } & JA & 2 & 2 & 1 & - & - & - & - & - & 5 & 1.53 \\
\hline & $\mathrm{BC}$ & 0 & 0 & 0 & - & - & - & - & - & 0 & \\
\hline & $\mathrm{CP}$ & 0 & 0 & 0 & - & - & - & - & - & 0 & \\
\hline \multirow[t]{2}{*}{6} & WP & 0 & 0 & 0 & - & - & - & - & - & 0 & \\
\hline & $\mathrm{NP}$ & 4 & 4 & 5 & - & - & - & - & - & 13 & \\
\hline \multirow[t]{3}{*}{4 Articles } & JA & 21 & 16 & 18 & 16 & - & - & - & - & 71 & 2.62 \\
\hline & $\mathrm{BC}$ & 1 & 1 & 1 & 1 & - & - & - & - & 4 & \\
\hline & $\mathrm{CP}$ & 6 & 7 & 6 & 5 & - & - & - & - & 24 & \\
\hline \multirow[t]{2}{*}{33} & WP & 1 & 3 & 2 & 3 & - & - & - & - & 9 & \\
\hline & $\mathrm{NP}$ & 4 & 6 & 6 & 8 & - & - & - & - & 24 & \\
\hline \multirow[t]{3}{*}{5 Articles } & JA & 20 & 15 & 16 & 17 & 12 & - & - & - & 80 & 3.49 \\
\hline & $\mathrm{BC}$ & 0 & 0 & 1 & 0 & 1 & - & - & - & 2 & \\
\hline & $\mathrm{CP}$ & 2 & 6 & 3 & 4 & 8 & - & - & - & 23 & \\
\hline \multirow[t]{2}{*}{26} & WP & 1 & 1 & 1 & 2 & 1 & - & - & - & 6 & \\
\hline & $\mathrm{NP}$ & 3 & 4 & 5 & 3 & 4 & - & - & - & 19 & \\
\hline \multirow[t]{3}{*}{6 Articles } & JA & 21 & 18 & 17 & 16 & 16 & 11 & - & - & 99 & 4.49 \\
\hline & $\mathrm{BC}$ & 0 & 0 & 0 & 0 & 0 & 0 & - & - & 0 & \\
\hline & $\mathrm{CP}$ & 3 & 5 & 5 & 5 & 4 & 5 & - & - & 27 & \\
\hline \multirow[t]{2}{*}{24} & WP & 0 & 1 & 1 & 2 & 2 & 6 & - & - & 12 & \\
\hline & NP & 0 & 0 & 1 & 1 & 2 & 2 & - & - & 6 & \\
\hline \multirow[t]{3}{*}{7 Articles } & JA & 1 & 0 & 1 & 1 & 2 & 2 & 1 & - & 8 & 5.21 \\
\hline & $\mathrm{BC}$ & 0 & 0 & 0 & 0 & 0 & 0 & 0 & - & 0 & \\
\hline & $\mathrm{CP}$ & 1 & 2 & 1 & 1 & 0 & 0 & 1 & - & 6 & \\
\hline \multirow[t]{2}{*}{2} & WP & 0 & 0 & 0 & 0 & 0 & 0 & 0 & - & 0 & \\
\hline & NP & 0 & 0 & 0 & 0 & 0 & 0 & 0 & - & 0 & \\
\hline \multirow[t]{3}{*}{8 Articles } & JA & 1 & 0 & 0 & 0 & 0 & 1 & 0 & 1 & 3 & 5.38 \\
\hline & $\mathrm{BC}$ & 0 & 0 & 0 & 0 & 0 & 0 & 0 & 0 & 0 & \\
\hline & $\mathrm{CP}$ & 0 & 1 & 1 & 0 & 1 & 0 & 0 & 0 & 3 & \\
\hline \multirow[t]{2}{*}{1} & WP & 0 & 0 & 0 & 0 & 0 & 0 & 0 & 0 & 0 & \\
\hline & NP & 0 & 0 & 0 & 1 & 0 & 0 & 1 & 0 & 2 & \\
\hline Total & & 92 & 92 & 92 & 86 & 53 & 27 & 3 & 1 & 446 & 3.34 \\
\hline
\end{tabular}

$J A$ journal article, $B C$ book chapter, $C P$ conference paper, $W P$ working papers, $N P$ non-published paper
Danish, 27 Finnish, 37 Swedish and 16 Norwegian dissertations. As given in Table 7, the dissertations vary in the number of included articles spanning from three to eight articles. The majority of the dissertations are composed of four to six articles. The average number of articles counts to 4.84. Table 7 also shows that the average dissertation score increases from 1.53 with three articles to 5.38 with eight articles. This is not surprising given the design of the formula.

Furthermore, Table 7 shows that including journal articles is a well-established practice among the reviewed dissertations. The share of journal articles counts $54 \%$ among dissertations with four articles (71/132); $62 \%$ among dissertations with five articles (80/130); and $69 \%$ among dissertations with six articles (99/144). After journal papers, conference papers and non-published papers are the second most typical types that are included in article- based dissertations. Finally, Table 7 shows that including reviewed books chapters is not that prevalent among the dissertations reviewed.

This review also shows that there are more $\mathrm{PhD}$ candidates at Chalmers University of Technology with highest number of contributions at 18 dissertations followed by Molde University College with 16 dissertations and Lund University with 11 dissertations (see Fig. 1). In all, the 92 article-based dissertations contain 446 articles divided into the five types discussed in Sect. 4.6.1. Out of this, 266 are peer-reviewed journal articles of which 68 are from Chalmers University of Technology; 39 are from Molde University College; and 39 are from Lappeenranta University of Technology. In total, 83 articles are included as conference papers; 64 are included as non-published papers; 27 are included as working papers; and only six articles take the form of book chapters. 
Fig. 1 Average dissertation scores divided by research institution. $A U$ Aalto University, $A S B / A U$ Aarhus School of Business/Aarhus University, CUT Chalmers University of Technology, HSE Hanken School of Economics, JIBS Jönköping International Business School, KI Karolinska Institutet, $\mathrm{LiU}$ Linköping University, $L U$ Lund University, LUT Lappeenranta University of Technology, MUC Molde University College, $S U$ Stockholm University, TSE Turku School of Economics, TUD Technical University Denmark, $U O$ University of Oulu, $U V$ University of Vaasa, USD University of Southern Denmark

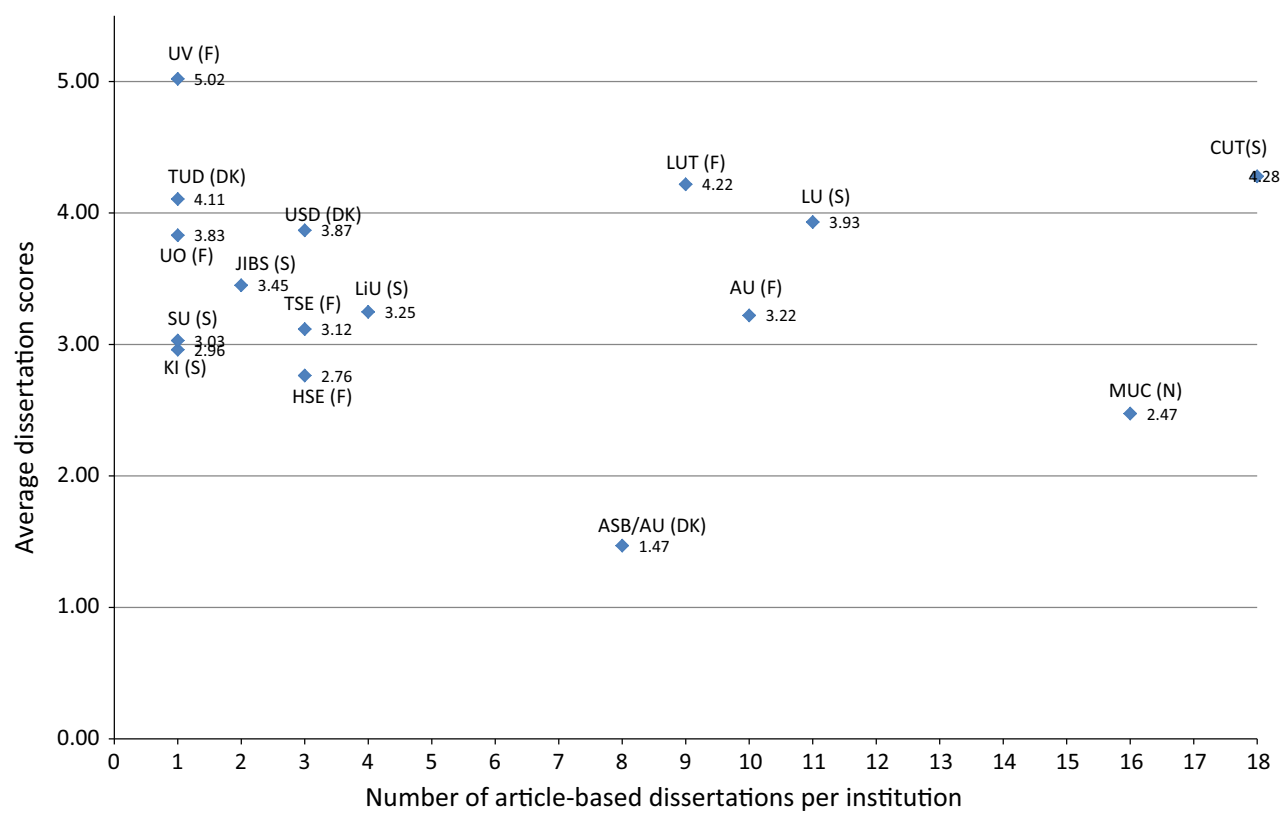

Figure 1 demonstrates a relatively high variety among the dissertations across the different research institutions with respect to the average institutional dissertations (ranging from 1.47, 2.47, 2.76, 2.96, 3.03, 3.12, 3.22, 3.25, $3.45,3.83,3.87,3.93,4.11,4.22,4.28,5.02)$. Four of the six dissertations composed of three articles (see Table 7) are Danish dissertations from Aarhus School of Business/ Aarhus University. In contrast, eight out of the 24 dissertations holding six articles are composed of 4-6 peer-reviewed journal articles. The dissertation score is here suggested as an instrument that can be used in discussions on what is required to earn the degree of $\mathrm{PhD}$ at the specific research institutions and, through benchmarks, facilitate alignment processes if needed. With the limitations in mind, a PhD student can discuss with her or his advisor(s) as of what type of articles are required; whether coauthored articles with advisors or other senior researchers or $\mathrm{PhD}$ students can be included; and how a PhD student documents her or his contribution in each article if they are co-authored. The dissertation score can also stimulate further discussions on what should be included in the binder of the dissertation-e.g., prioritizes theme to be discussed in the binder instead of adding another article.

\subsection{Potential topics for inclusion in the dissertations}

The review process of the 150 dissertations reveals that five research areas seem to be under-prioritized among Nordic scholars within logistics and SCM. The topics are as follows (not prioritized):

(1) Cloud technology Although there is a focus on maximizing the effectiveness of shared resources [5], the increased availability of high-capacity network, low-cost computers and storage devices as well as the widespread adoption of hardware virtualization, service-oriented architecture, and autonomic and utility computing have led to a growth in the use of cloud technology. In spite of its increased importance, it is distinct that this subject has not received more attention in the dissertations reviewed.

(2) Globalization of SC As mentioned previously, this topic was still largely ignored in the dissertation reviewed. With the natural outcome of expanding growing market and sustaining competitive advantage, companies have to make key decisions about managing costs and complexity through globalized supply chain (see, e.g., [11]).

(3) Supply chain innovation (SCI) The discipline of innovations has branched out into the supply chain context and should be regarded as an important topic. While firms are applying their assets, operating resources and capabilities to develop new ways of improve performance, they cannot ignore the importance of their supply chain partners in enabling product and process innovations (see, e.g., [1]). Accordingly, more attention needs to be paid to this topic.

(4) Security This topic was also mentioned in the previous study by Zachariassen and Arlbjørn [41]. Yet, this topic has only received limited attention among the 112 dissertations published between 2009 and 2014. Security is increasingly becoming a major concern to both private and public sector organizations. Security searches for cooperative arrangements between businesses as well as identifies risks 
before the goods move. It is also concerned with controlling theft and reducing illegal import and export of stolen goods. There are many areas of research within the topic of security from formal aspects to empirical research (see, e.g., [4, 40]). Hence, it is essential that researchers start focusing on the different aspects of this topic in the future. This is one of the key topics of research within supply chain now as well as in the distant future.

(5) Big data This is currently drowning the world. The huge amount of data is an invaluable asset in the context of supply chains. The quality of the evidence extracted significantly benefits from the availability of broad datasets. On the one hand, extensive vision is more promising when extra data are available. And, on the other hand, it is a big challenge. The current approach is not appropriate to handle large data, and therefore, there is a need for new solutions to handle large datasets. This research field is new and rapidly evolving [38], and there is also a leadtime issue before we see the first dissertations within this area. As a result, any initial effort taken will be a strong contribution from both experimental and theoretical perspective (see, e.g., [15]).

\section{Conclusion}

This paper has set out to analyze the development of Nordic doctoral dissertations in logistics and SCM from the years 2009-2014. The paper identified 158 dissertations relevant for review; out of this, 150 dissertations were reviewed in depth based on different criteria. Compared with previous studies, this research found several important developments in Nordic doctoral research. First, there has been an increase in the average annual number of finalized dissertations when compared to previous Nordic studies. The results predominantly show the remarkable increase in dissertations between 2009 and 2014 (158 dissertations) wherein Sweden ranks highest followed by Finland, Norway, Denmark and Iceland, respectively. Second, there has been a decrease in dissertations that focus on classical entities of analysis such as carriers, wholesalers, retailers and inventories. Therefore, it is clear that the $\mathrm{PhD}$ dissertation's focal point is still more on manufacturing firms (50/150) rather than on other entities. Third, there has been an increase in functional subject areas of logistics and SCM and the supply chain/network level. Fourth, the number of dissertations containing philosophy of science discussions is continuing to decline. As mentioned earlier, there is a significant increase in article-based dissertations and these dissertations do not adopt philosophy of science; as a result, there is an extreme decrease (110/150). Finally, there is clear shift toward disseminating doctoral research as an article-based dissertation (2009-2014: 92/150; 2002-2008: 26/70; 1990-2001: 15/71, respectively). However, this piece of research has demonstrated that the content of the Nordic article-based dissertations varies along dimensions such as types of articles included, the number of articles included and the number of co-authors at the papers. A dissertation score has been suggested as a measure for initiating discussions about such dissertations at a single research institution and as a benchmark between different institutions. As discussed earlier, such a score is not without limitations and must not stand alone. Therefore, the next logical step might be to discuss how far should we go with the number and the type of contributions. What is enough in order to earn a $\mathrm{PhD}$ degree? The content of this paper can be used to match the expectations of PhD students and their supervisors so as to find the right path to learn the craft of conducting and disseminating logistics and SCM research.

Open Access This article is distributed under the terms of the Creative Commons Attribution 4.0 International License (http://crea tivecommons.org/licenses/by/4.0/), which permits unrestricted use, distribution, and reproduction in any medium, provided you give appropriate credit to the original author(s) and the source, provide a link to the Creative Commons license, and indicate if changes were made.

\section{Appendix 1: Research institutions contacted}

\section{Denmark}

- Aalborg University

- Aarhus School of Business/Aarhus University

- Copenhagen Business School

- Danish Technical University/Technical University of Denmark

- Roskilde University

- University of Southern Denmark

\section{Finland}

- Aalto University

- Åbo Akademi University

- Hanken School of Economic

- Helsinki University

- Lappeenranta University of Technology

- National Defence University

- Swedish School of Economics and Business Administration

- Tampere University of Technology

- Technical Research Center of Finland

- Turku School of Economics 
- University of Oulu Business School

- University of Vaasa

\section{Iceland}

- University of Iceland

\section{Norway}

- BI Norwegian School of Management

- Institute of Transport Economics

- Molde University College

- Norwegian School of Economics and Business Administration

- Norwegian University of Science and Technology

- SINTEF Industrial Management

- University of Oslo Business School

- University of Nordland

\section{Sweden}

- Chalmers University of Technology

- Gothenburg University

- Jönköping International Business School

- Karolinska Institute Department of Public Health Sciences

- Linköping University

- Linnæus University

- Lund University

- Örebro University

- Stockholm School of Economics

- Stockholm University

- Swedish National Road and Transport Research Institute

- University College of Borås

\section{Appendix 2: Doctoral dissertations identified}

\section{Danish dissertations}

Aarhus School of Business/Aarhus University:

- Abginehchi, S. (2012), Essays on Inventory Control in Presence of Multiple Sourcing, Aarhus.

- Bach, L. (2014), Routing and Scheduling ProblemsOptimization using Exact and Heuristic Methods, Aarhus.

- Bendre, A.B. (2010), Numerical Studies of Singlestage, Single-item Inventory Systems with Lost Sales, Aarhus.

- Bodnar, P. (2013), Essays on Warehouse Operations, Aarhus.

- Christensen, T.R.L. (2013), Network Design Problems with Piecewise Linear Cost Functions, Aarhus.
- Du, B. (2011), Essays on Advance Demand Information, Prioritization and Real Options in Inventory Management, Aarhus.

- Hanghøj, A. (2014), Papers in Purchasing and Supply Management: A Capability-Based Perspective, Aarhus.

- Kjeldsen, K.H. (2012), Routing and Scheduling in Liner Shipping, Aarhus.

Copenhagen Business School:

- Andreasen, P.H. (2012), The Dynamics of Procurement Management-A Complexity Approach, Frederiksberg.

- Kinra, A. (2009), Supply Chain (Logistics) Environmental Complexity, Frederiksberg.

- Nøkkentved, C. (2009), Enabling Supply Networks with Collaborative Information Infrastructures: An Empirical Investigation of Business Model Innovation in Supplier Relationship Management, Frederiksberg.

- Yu, L.A. (2012), Fabricating an S\&OP Process: Circulating References and Matters of Concern, Frederiksberg.

University of Southern Denmark:

- Jensen, J.K. (2013), Development of Environmentally Sustainable Food Supply Chains, Kolding.

- Mikkelsen, O.S. (2011), Strategic Sourcing in a Global Organizational Context, Kolding.

- Mortensen, M.H. (2011), Towards Understanding Attractiveness in Industrial Relationships, Kolding.

- Zachariassen, F. (2011), Supply Chain Management and Critical Theory: Meta-Theoretical, Disciplinary and Practical Contributions to the Supply Chain Management Discipline Based on Insights from the Management Accounting Discipline, Kolding.

Technical University of Denmark:

- Jørgensen, P. (2013), Technology in Health Care Logistics, Lyngby.

\section{Finnish dissertations}

Aalto University School of Business:

- Aaltonen, K. (2010), Stakeholder Management in International Projects, Finland.

- Ahola, T. (2009), Efficiency in Project Networks: The Role of Inter-Organizational Relationships in Project Implementation, Finland.

- Ala-Risku, T. (2009), Installed Base Information: Ensuring Customer Value and Profitability after the Sale, Finland. 
- Groop, J. (2012), Theory of Constraints in Field Service: Factors Limiting Productivity in Home Care Operations, Finland.

- Helkiö, P. (2013), Developing Explorative and Exploitative Strategic Intentions-Towards a Practice Theory of Operations Strategy, Finland.

- Hinkka, V. (2013), Implementation of RFID Tracking across the Entire Supply Chain, Finland.

- Karjalainen, K. (2009), Challenges of Purchasing Centralization-Empirical Evidence from Public Procurement, Finland.

- Karrus, K. (2011), Policy Variants for Coordinating Supply Chain Inventory Replenishments, Finland.

- Kauremaa, J. (2010), Studies on the Utilization of Electronic Trading Systems in Supply Chain Management, Finland.

- Nieminen, S. (2011), Supplier Relational Effort in the Buyer-Supplier Relationship, Finland.

- Peltokorpi, A. (2010), Improving Efficiency in Surgical Services: A Production Planning and Control Approach, Finland.

- Porkka, P. (2010), Capacitated Timing of Mobile and Flexible Service Resources, Finland.

- Rajahonka, M. (2013), Towards Service ModularityService and Business Model Development, Finland.

- Ristola, P. (2012), Impact of Waste-to-Energy on the Demand and Supply Relationships of Recycled Fibre, Finland.

- Seppälä, T. (2014), Contemporary Determinants and Geographical Economy of Added Value, Cost of Inputs, and Profits in Global Supply Chains: An Empirical Analysis, Finland.

- Tenhiälä, A. (2009), Contingency Theories of Order Management, Capacity Planning, and Exception Processing in Complex Manufacturing Environments, Finland.

- Torkki, P. (2012), Best Practice Processes-What are the Reasons for Differences in Productivity between Surgery Units, Finland. NOT reviewed

- Turunen, T. (2013), Organizing Service Operations in Manufacturing, Finland.

- Tynjälä, T. (2011), An Effective Tool for Supply Chain Decision Support During New Product Development Process, Finland.

- Viitamo, E. (2012), Productivity as a Competitive Edge of a Service Firm: Theoretical Analysis and a Case Study of the Finnish Banking Industry, Finland.

- Voutilainen, J. (2014), Factory Positioning in an Unpredictable Environment: A Managerial View of Manufacturing Strategy Formation, Finland.

Åbo Akademi University:
- Nyholm, M. (2011), Activation of Supply Relationships, Turku.

Hanken School of Economic:

- Antai, I. (2011), Operationalizing Supply Chain vs. Supply Chain Completion, Finland.

- Haavisto, I. (2014), Performance in Humanitarian Supply Chains, Finland.

- Harilainen, H. (2014), Managing Supplier Sustainability Risk, Finland.

- Tomasini Ponce, R. (2012), Informal Learning Framework for Secondment: Logistics Lessons from Disaster Relief Operations, Finland.

- Vainionpää, M. (2010), Tiering Effects in Third-party Logistics: A First-Tier Buyer Perspective, Finland.

University of Oulu Business School:

- Juntunen, J. (2010): Logistics Outsourcing for Economies in Business Network, Finland

Lappeenranta University of Technology-Industrial Engineering and Management:

- Karppinen, H. (2014), Reframing the Relationship between Service Design and Operations: A Service Engineering Approach, Lappeenranta.

- Kerkkänen, A. (2010), Improving Demand Forecasting Practices in the Industrial Context, Lappeenranta.

- Laisi, M. (2013), Deregulation's Impact on the Railway Freight Transport Sector's Future in the Baltic Sea Region, Lappeenranta.

- Lättilä, L. (2012), Improving Transportation and Warehousing Efficiency with Simulation-Based Decision Support Systems, Lappeenranta.

- Niemi, P. (2009), Improving the Effectiveness of Supply Chain Development Work-An Expert Role Perspective, Lappeenranta.

- Pekkanen, P. (2011), Delay Reduction in Courts of Justice-Possibilities and Challenges of Process Improvement in Professional Public Organizations, Lappeenranta.

- Salmela, E. (2014), Kysyntä-Toimitusketjun Synkronointi Epävarman Kysynnän ja Tarjonnan Toimintaympäristössä, Lappeenranta. NOT reviewed.

- Saranen, J. (2009), Enhancing the Efficiency of Freight Transport by Using Simulation, Lappeenranta.

Lappeenranta University of Technology-School of Business:

- Kähkönen, A. (2010), The Role of Power Relations in Strategic Supply Management-A Value Net Approach, Lappeenranta. 
- Lintukangas Annaliisa, K. (2009), Supplier Relationship Management Capability in the Firm's Global Integration, Lappeenranta.

- Vilko, J. (2012), Approaches to Supply Chain Risk Management: Identification, Analysis and Control, Lappeenranta.

Turku School of Economic:

- Koskinen, P. (2009), Supply Chain Challenges and Strategies of a Global Paper Manufacturing Company, Turku.

- Lorentz, H. (2009), Contextual Supply Chain Constraints in Emerging Markets-Exploring the Implications for Foreign Firms, Turku.

- Rantasila, K. (2013), Measuring Logistics Costs. Designing a Generic Model for Assessing Macro Logistics Costs in a Global Context with Empirical Evidence from the Manufacturing and Trading Industries, Turku.

- Solakivi, T. (2014), The Connection between Supply Chain Practices and Firm Performance-Evidence from Multiple Surveys and Financial Reporting Data, Turku.

Tampere University of Technology:

- Jokinen, J. (2010), Multi-Agent Control of Reconfigurable Pallet Transport Systems, Tampere. NOT reviewed

University of Vaasa:

- Addo-Tenkorang, R. (2014), Conceptual Framework for Large-Scale Complex Engineering- Design \& Delivery Processes. A Case of Enterprise SCM Network Activities and Analysis, Finland.

- Kärki, P. (2012), The Impact of Customer Order Lead Time-Based Decisions on the Firm's Ability to Make Money-Case Study: Build to Order Manufacturing of Electrical Equipment and Appliances, Finland.

- Moilanen, V. (2011), Case study: Developing a Framework for Supply Network Management, Finland.

- Nugroho Widhi, Y K. (2009), Structuring Postponement Strategies in the Supply Chain by Analytical Modeling, Finland.

\section{Icelandic dissertations}

University of Iceland-School of Health Sciences:

- Nga, M. (2010), Enhancing Quality Management of Fresh Fish Supply Chains through Improved Logistics and Ensured Traceability, Reykjavik.

\section{Norwegian dissertations}

Norwegian University of Science and Technology:

- Bai, Y. (2013), Reliability of International Freight Trains, An Exploratory Study Drawing on Three Mainstream Theories, Trondheim.

BI Norwegian School of Management:

- Hatteland, C.J. (2010), Ports as Actors in Industrial Networks, Norway.

- Bjørnstad, S. (2009), Shipshaped Kongsberg Industry and Innovations in Deepwater Technology, 1975-2000, Norway.

- Hoholm, T. (2009), The Contrary Forces of InnovationAn Ethnography of Innovation Processes in the Food Industr, Norway.

- Zhovtobryukh, Y (2014), The Role of Technology, Ownership and Origin in M\&A Performance, Norway.

Molde University College:

- Halse, L.L. (2014), Walking the Path of Change. Globalization of the Maritime Cluster in North West Norway, Norway.

- Salema, G.L. (2014), The Antecedents of Supplier Logistics Performance: an Empirical Study of the Essential Medicines Supply in Tanzania, Norway.

- Chaudhry, M.O. (2014), An Assessment of Linkages between Investment in Transport Infrastructure and Economic Development, Norway.

- Søvde, N.E. (2014) Optimization of Terrain Transportation Problems in Forestry, Norway.

- Iversen, H.P. (2013) Logististikkerfaringer i Psykiatri og Psykisk Helsearbeid: Om Forståelse, Organisering og Ledelsed av Relasjoner $i$ en Profesjonell Organisasjon i Omstilling, Norway.

- Bottolfsen, T. (2013) The Impact of Internal, Customer and Supplier Integration on Store Performance, Norway.

- Schøyen, H. (2013) Identifying Efficiency Potentials in Maritime Logistics: Investigations from Container and Bulk Trades, Nowary.

- Jin, J.Y. (2013) Cooperative Parallel Metaheuristics for Large Scale Vehicle Routing Problems, Norway.

- Regmi, U.K. (2013) Essays on Air Transport Marketing and Economics, Norway.

- Glavee-Geo, R. (2012) The Antecedents and Consequences of Supplier Satisfaction in Agro Commodity Value Chain: an Empirical Study of Smallholder Cocoa Growers of Ghana, Norway.

- Lanquepin, G. (2012) Algorithms for Dynamic Pricing and Lot Sizing, Norway. 
- Qin, F.F. (2012) Essays on Efficient Operational Strategy of Urban Rail Transit, Norway.

- Qian, F.B. (2012) Passenger Risk Minimization in Helicopter Transportation for the Offshore Petroleum Industry, Norwary.

- Bø, O. (2012) Aspects of Production Tracking Systems in the Supply Network for Caught Seafood, Norway.

- Yue, X. (2010) Competition and Cooperation: a Game theoretic Analysis on the Development of Norwegian Continental shelf, Norway.

- Shyshou, A. (2010) Vessel Planning in Offshore Oil and Gas Operations, Norway.

- Thapalia, B.K. (2010) Stochastic Single-commodity Network Design, Norway.

- Bakhrankova, K. (2010) Production Planning in Continuous Process Industries: Theoretical and Optimization Issues, Norway.

- Bhatta, B.P. (2009) Discrete Choice Analysis with Emphasis on Problems of Network-based Level of Service Attributes in Travel Demand Modeling, Norway.

- Burki, U. (2009) Cross Cultural Effects on the Relational Governance of Buyer-Supplier Relationships: an Empirical Study of the Textile Exporting Firms of Pakistan, Norway.

- Vaagen, H. (2009) Assortment Planning under Uncertainty, Norway.

- Saeed, N. (2009) Competition and Cooperation among Container Terminals in Pakistan: with Emphasis on Game Theoretical Analysis, Norway.

\section{Swedish dissertations}

\section{Chalmers University of Technology:}

- Almotairi, B. (2012), Integrated Logistics Platform the Context of the Port Relational Exchanges and Systematic Integration, Gothenburg.

- Andersson, R. (2009), Supply Chain Resilience through Quality Management, Gothenburg.

- Bankvall, L. (2011), Activity Linking in Industrial Networks, Gothenburg.

- Behrends, S. (2011), Urban Freight Transport Sustainability-The Interaction of Urban Freight and Intermodal Transport, Gothenburg.

- Ekwall, D. (2009), Managing Risk for Antagonistic Threats against Transport Network, Gothenburg.

- Ellis, J. (2011), Assessing Safety Risks for the Sea Transport Link of a Multimodal Dangerous Goods Transport Chain, Gothenburg.

- Finnsgård, C. (2013), Materials Exposure: The Interface between Materials Supply and Assembly, Gothenburg.
- Fredriksson, A. (2011), Materials Supply and Production Outsourcing, Gothenburg.

- Hanson, R. (2012), In-Plant Materials Supply: Supporting the Choice between Kitting and Continuous Supply, Gothenburg.

- Hilletofth, P. (2010), Demand-Supply Chain Management, Gothenburg.

- Hjort, K. (2013), On Aligning Returns Management with the Ecommerce Strategy to Increase Effectiveness, Gothenburg.

- Ingrid, H. (2014), Organizing Purchasing and Supply Management across Company Boundaries, Gothenburg.

- Ivert, L. (2012), Use of Advanced Planning and Scheduling (APS) Systems to Support Manufacturing Planning and Control Processes, Gothenburg.

- Kalantari, J. (2012) Foliated Transportation NetworksEvaluating Feasibility and Potential, Gothenburg.

- Kharrazi, S. (2012), Steering Based Lateral Performance Control of Long Heavy Vehicle Combinations, Gothenburg.

- Lindholm, M.E., (2012) Enabling Sustainable Development of Urban Freight from a Local Authority Perspective, Gothenburg.

- Mirzabeiki, V. (2013), Collaborative Tracking and Tracing-A Supply Chain Perspective, Gothenburg.

- Roso, V. (2009), The Dry Port Concept, Gothenburg.

- Sternberg, H. (2011), Waste in Road Transport Operations-Using Information Sharing to Increase Efficiency, Gothenburg.

- Styhre, L. (2010), Capacity Utilization in Short Sea Shipping, Gothenburg.

- Sundquist, V. (2014), The Role of Intermediation in Business Networks, Gothenburg.

- Thörnblad, K. (2013), Mathematical Optimization in Flexible Job Shop Scheduling: Modelling, Analysis, and Case Studies, Gothenburg.

Jönköping International Business School:

- Borgström, B. (2010), Supply chain strategising: Integration in practice, Jönköping.

- Cui, L.G., (2012), Innovation and network development of logistics firms, Jönköping.

- Skoglund, P. (2012), Sourcing decisions for military logistics in Peace Support Operations: A case study of the Swedish armed forces, Jönköping.

- Jafari, H. (2014), Postponement and Logistics Flexibility in Retailing, Jönköping.

- Wikner, S. (2011), Value Co-creation as Practice-On a supplier's capabilities in the value generation process, Jönköping.

Karolinska Institute Department of Public Health Sciences:

- Anund, A. (2009), Sleepiness at the Wheel, Sweden. 
Linköping University:

- Ekström, J. (2012), Optimization Approaches for Design of Congestion Pricing Schemes, Linköping.

- Feldmann, A. (2011), A Strategic Perspective on Plants in Manufacturing Networks, Linköping.

- Hansson, L. (2010), Public Procurement at the Local Government Level: Actor Roles, Discretion and Constraints in the Implementation of Public Transport Goals, Linköping.

- Isaksson, K. (2014), Logistics Service Providers Going Green-A Framework for Developing Green Service Offerings, Linköping.

- Lindskog, M. (2012), On Systems Thinking in Logistics Management-A Critical Perspective, Linköping.

- Malmgren, M. (2010), Managing Risks in Business Critical Outsourcing: A Perspective from the Outsourcer and the Supplier, Linköping.

- Martinsen, U. (2014), Towards Greener Supply Chains: Inclusion of Environmental Activities in Relationships between Logistics Service Providers and Shippers, Linköping.

- Mårdh, S. (2013), Cognitive Erosion and its Implications in Alzheimer's Disease, Linköping.

- Musa, S.N. (2012), Supply Chain Risk Management: Identification, Evaluation and Mitigation Techniques, Linköping.

- Olstam, J. (2009), Simulation of Surrounding Vehicles in Driving Simulators, Linköping.

- Thoresson, K. (2011), To Calculate the Good Society: Cost-Benefit Analysis and the Border between Expertise and Policy in the Transport Sector, Linköping. NOT reviewed.

Linnaeus University:

- Farvid, S.M. (2014), Essays on Inventory Theory, Sweden.

- Samadi, R. (2010), Supply Chain Optimization and Market Coordinated Inventory, Sweden. NOT Reviewed.

Lund University:

- Bagdadi, O. (2012), The Development of Methods for Detection and Assessment of Safety Critical Events in Car Driving, Lund.

- Eng Larsson, F. (2014), On the Incentives to Shift to Low-Carbon Freight Transport, Lund.

- Howard, C. (2013), Real-Time Allocation Decisions in Multi-Echelon Inventory Control, Lund.

- Lundin, J. (2011), On Supply Chain Incentive Alignment: Insight from a Cash Supply Chain and a Trucking Service Supply Chain, Lund.
- Olander, M. (2010), Logistik och Juridik. Moderna Affärsförbindelser och Kontrakt som Utmaningar för Förmögenhetsrätten, Lund. NOT Reviewed

- Pazirandeh, A. (2014), Purchasing Power and Purchasing Strategies-Insights from the Humanitarian Sector, Lund.

- Urciuoli, L. (2011), Security in Physical Distribution Networks: A Survey Study of Swedish Transport Operators, Lund.

- Olander Roses, K. (2014), From PowerPoints to Reality-managing Strategic Change in the Paper Packaging Industry, Lund.

- Sohrabpour, V. (2014), Packaging Design and Development for Supply Chain Efficiency and Effectiveness, Lund.

- Abbasi, M. (2014), Exploring Themes and Challenges in Developing Sustainable Supply Chains-A Complexity Theory Perspective, Lund.

- Ringsberg, H. (2013), Food Traceability in Regulated Fresh Food Supply Chains with an Emphasis on the Swedish Fishing Industry, Lund.

- Beckeman, M. (2011), The Potential for Innovation in the Swedish Food Sector, Lund.

- Dominic, C. (2011), Packaging Logistics Performance, Lund.

- Johansson, O. (2009), On the Value of Intelligent Packaging-A Packaging Logistics Perspective, Lund.

- Pålsson, H. (2009), Logistics value of using tracking data from uniquely labelled goods, Lund.

Stockholm University, Department of Psychology:

- Eriksson, G. (2014), On Physical Relations in Driving: Judgments, Cognition and Perception, Stockholm.

Örebro University School of Business:

- Ahlberg, J. (2012), Multi-Unit Common Value Auctions: Theory and Experiments, Örebro.

- Arvidsson, S. (2010), Essays on Asymmetric Information in the Automobile Insurance Market, Örebro.

- Bohlin, L. (2010), Taxation of Intermediate Goods-A CGE Analysis, Örebro.

- Krüger, N. (2009), Infrastructure Investment Planning under Uncertainty, Örebro. NOT reviewed

- Liu, X. (2013), Transport and Environmental Incentive Policy Instruments-Effects and Interactions, Örebro. NOT reviewed

- Lodefalk, M. (2013), Tackling Barriers to Firm Trade. Liberalisation, Migration, and Servicification, Örebro.

- Sund, B. (2010), Economic Evaluation, Value of Life, Stated Preference Methodology and Determinants of Risk, Örebro.

- Swärdh, J. (2009), Commuting Time Choice and the Value of Travel Time, Örebro. 


\section{References}

1. Arlbjørn JS, de Haas H, Munksgaard KB (2011) Exploring supply chain innovation. Logist Res 3(1):3-18

2. Arlbjørn JS, Freytag PV, Damgaard T (2008) The beauty of measurement. Eur Bus Rev 20(2):112-127

3. Arlbjørn JS, Halldórsson Á (2002) Logistics knowledge creation: reflections on content, context and processes. Int J Phys Distr Log 32(1):22-40

4. Blackhurst J, Ekwall D, Martens BJ (2015) Special issue on supply chain security. Int J Phys Distr Log 45(7). doi:10.1108/ IJPDLM-04-2015-0104

5. Cegielski CG, Allison Jones-Farmer L, Wu Y, Hazen BT (2012) Adoption of cloud computing technologies in supply chains: an organizational information processing theory approach. Int $\mathbf{J}$ Logist Manag 23(2):184-211

6. Choi TY, Wacker JG (2011) Theory building in the OM/SCM field: pointing to the future by looking at the past. Supply Chain Manag Int J 47(2):8-11

7. Committee on Publication Ethics (COPE) (2014) How to deal with text recycling. http://publicationethics.org/files/BioMed\% 20Central_text_recycling_editorial_guidelines_1.pdf. Accessed 09 Jan 2016

8. Das A, Handfield RB (1997) A meta-analysis of doctoral dissertations in purchasing. J Oper Manag 15(2):101-121

9. Dyrud MA (2015) Ethics and text recycling. In: 122nd ASEE annual conference \& exposition, 14-17 June 2015, Seattle, paper ID\#11150

10. Fernie J, Sparks L, McKinnon AC (2010) Retail logistics in the UK: past, present and future. Int J Retail Distr Manag 38(11/ 12):894-914

11. Gereffi G, Lee J (2012) Why the world suddenly cares about global supply chains. Supply Chain Manag Int J 48(3):24-32

12. Group of Eight (2013) The changing. In: Ph.D.: discussion paper. O'Conner ACT Australia. https://go8.edu.au/sites/default/files/ docs/the-changing-phd_final.pdf. Accessed 01 March 2015

13. Gubi E, Stentoft Arlbjørn J, Johansen J (2003) Doctoral dissertations in logistics and supply chain management: a review of Scandinavian contributions from 1990 to 2001. Int J Phys Distr $\log 33(10): 854-885$

14. Halldórsson Á, Larson PD, Poist RF (2008) Supply chain management: a comparison of Scandinavian and American perspectives. Int J Phys Distr Log 38(2):126-142

15. Huang YY, Handfield RB (2015) Measuring the benefits of ERP on supply management maturity model: a "big data" method. Int J Oper Prod Man 35(1):2-25

16. Hughes M (2014) Editorial: reflecting on ethical questions and peer reviewing. Aust Soc Work 67(4):463-466

17. Jørgensen P (2013) Technology in health care logistics. Dissertation, Technical University of Denmark

18. Karjalainen K (2009) Challenges of purchasing centralizationempirical evidence from public procurement. Dissertation, Aalto University School of Business

19. Karrus KE (2011) Policy variants for coordinating supply chain inventory replenishments. Dissertation, Aalto University School of Business

20. Macdonald S, Kam J (2007) Ring a Ring o'Roses: quality journals and gamesmanship in management studies. J Manag Stud 44(4):640-655

21. McKinnon AC (2013) Starry-eyed: journal rankings and the future of logistics research. Int J Phys Distr Log 43(1):6-17
22. Menachof DA, Gibson BJ, Hanna JB, Whiteing AE (2009) An analysis of the value of supply chain management periodicals. Int J Phys Distr Log 39(2):145-165

23. Mortensen, MH (2011) Towards understanding attractiveness in industrial relationships. Dissertation, University of Southern Denmark

24. Myklebust, JP (2013). Sharp rise in foreign. In: Ph.D. enrolments in Scandinavia. University World News 18

25. Nakhata C, Stock JR, Texiera TB (2013) Doctoral dissertations in logistics and supply chain-related areas: 2005-2009. Logist Res 6(4):119-131

26. Nga, MTT (2010) Enhancing quality management of fresh fish supply chains through improved logistics and ensured traceability. Dissertation, University of Iceland

27. Rao S, Iyengar D, Goldsby JT (2013) On the measurement and benchmarking of research impact among active logistics scholars. Int J Phys Distr Log 43(10):814-832

28. Stock JR (1987) A compendium of doctoral research in logistics: 1970-1986. J Bus Logist 8(2):123-136

29. Stock JR (1988) A compendium of doctoral research in logistics: 1970-1986. J Bus Logist 9(1):125-233

30. Stock JR (1997) Applying theories from other disciplines to logistics. Int J Phys Distr Log 27(9/10):515-539

31. Stock JR (2001) Doctoral research in logistics and logistics-related areas 1992-1998. J Bus Logist 22(1):125-256

32. Stock JR, Boyer SL (2009) Developing a consensus definition of supply chain management: a qualitative study. Int J Phys Distr Log 39(8):690-711

33. Stock JR, Broadus CJ (2006) Doctoral research in supply chain management and/or logistics-related areas: 1999-2004. J Bus Logist 27(1):139-151

34. Stock JR, Luhrsen DA (1993) Doctoral research in logistics-related areas 1987-1991. J Bus Logist 14(2):197-210

35. Tynjälä T (2011) An effective tool for supply chain decision support during new product development process. Dissertation, Aalto University School of Business

36. Undervisnings \& Forsknings Ministeriet (Ministry of Teaching and Research) (UFM) (2015a) http://ufm.dk/forskning-og-inno vation/statistik-og-analyser/den-bibliometriske-forskningsindikator/ autoritetslister/list-of-series-18112015-xlsx.pdf. Accessed 31 Dec 2015

37. Undervisnings \& Forsknings Ministeriet (Ministry of Teaching and Research) (UFM) (2015b) http://ufm.dk/forskning-og-inno vation/statistik-og-analyser/den-bibliometriske-forskningsindikator/ autoritetslister/autoritetslisten-for-forlag-2015-november-xlsx.pdf. Accessed 31 Dec 2015

38. Waller M, Fawcett S (2013) Data science, predictive analytics, and big data: a revolution that will transform supply chain design and management. J Bus Logist 34(2):77-84

39. Williams AJ (1986) Doctoral research in purchasing and materials management: an assessment. J Purch Mater Manage 22(1):13-16

40. Williams Z, Lueg JE, Taylor RD, Cook RL (2009) Why all the changes? An institutional theory approach to exploring the drivers of supply chain security (SCS). Int J Phys Distr Log 39(7):595-618

41. Zachariassen F, Arlbjørn JS (2010) Doctoral dissertations in logistics and supply chain management: a review of Nordic contributions from 2002 to 2008. Int J Phys Distr Log 40(4):332-352 